\title{
Survival Tactics of Waste Paper Pickers in Istanbul ${ }^{1}$
}

\author{
Ismail Yigit ${ }^{2}$ \\ Mississippi State University, USA
}

\begin{abstract}
This study examines migration, ethnicity, stratification, and the informal economy by focusing on Waste Paper Pickers (WPPs) as an informal occupational group in Istanbul. I conducted a yearlong fieldwork project among WPPs in Istanbul, collecting ethnographic, observational, participant observational and interview data to develop a description of the everyday lives of WPPs and how they organize their daily work routines. This paper identified most WPPs as immigrants enmeshed in family, friend and compatriot relationships and examined differences and similarities among WPPs. Three main factors account for immigrants entering this occupation: (1) kinship / relative / friend and compatriot relations, (the WPPs' social capital); (2) the easy entry to this occupation; and, (3) the 'mafia' or hiring WPPs on daily basis. Rather than only one type of WPP, they can better be understood as falling into five different types. WPPs in each type differ in their work, the way they work, the money they earn, and their relations with local people. Among my informants, some WPPs can be seen to fit into more than one type while others fall only into one. These types are: (1) Old-hand WPPs, (2) Beginner WPPs, (3) Drunk WPPs, (4) Hired WPPs, and (5) Seasonal WPPs.
\end{abstract}

Key Words: Waste Paper Picking, Migration, Informality, Istanbul.

\section{Introduction}

Like most mega-cities in developing countries, Istanbul is experiencing stress from population increase and rapid urbanization. This urban growth puts pressure on waste management in Istanbul, too, straining the abilities of municipalities to address waste management needs effectively. Waste pickers take advantage of the inadequate formal waste management programs by collecting useable and renewable materials from the streets of Istanbul. Waste Paper Pickers (WPPs) not only meet their own economic needs but also provide benefits to their communities, their municipalities and the environment.

Immigrants, forced immigrants, lower-class people, unskilled people, or drunken people in Istanbul use Waste picking as a 'tactic' employed. Current study focuses on migration, ethnicity, and the informal economy by focusing on Waste Paper Pickers (WPPs) as an informal occupational group in Istanbul. This study conducted a yearlong fieldwork project among WPPs in Istanbul, collecting ethnographic, observational, participant observational and interview data to develop a description of the everyday lives of WPPs. Current study identified most WPPs as immigrants enmeshed in family, friend, and compatriot relationships and examines differences and similarities among WPPs. This study focused on internal, legal migrants, some voluntary and some involuntary, and on these migrants' experiences in the informal economy.

Based on data, three main factors account for immigrants entering this occupation: (1) kinship / relative / friend and compatriot relations, (the WPPs' social capital); (2) the easy entry to this occupation; and, (3) the 'mafia' or hiring WPPs on daily basis. Rather than only one type of WPP, they can better be understood as falling into five different types. WPPs in each type differ in their work, the way they work, the money they earn, and their relations with local people. Among my informants, some WPPs can be seen to fit into more than one type while others fall only into one. These types are: (1) Old-hand WPPs, (2) Beginner WPPs, (3) Drunk WPPs, (4) Hired WPPs, and (5) Seasonal WPPs.

This study has four sub-titles. It focused on the scholarly literature about WPPs both inside and outside Turkey. It explores the role of WPPs worldwide as well as in Turkey. Secondly also examines the structure of informal occupations and the match between migration and migrant WPPs as an informal occupation. Thirdly it outlines the methods used in this study and why these methods are

\footnotetext{
${ }^{1}$ This paper is produced from author's Master Thesis.

${ }^{2}$ PhD Candidate in Department of Sociology, E-mail: ihy1@msstate.edu
} 
useful and appropriate. Fourthly it presents the data and its analyses. I show the role of immigration in the composition of this occupational group - how they migrated and when, and how immigration affects the dynamics of this occupation. I described the daily routines of my informants and developed a typology of WPPs and how WPPs interact with each other and also with other people. Lastly, this paper presents my conclusions drawn from my research.

\section{Literature Review}

\section{Role of WPPs in Worldwide Waste Management}

The proportions of wastes are at a low level in rural areas. People burn their wastes or bury those wastes in rural areas. However wastes are visible and have a significant economic value in cities. Wastes must be collected from cities as much as achievable, since, the more it stays in the streets the more it causes health problem for inhabitants and animals. 'Waste' can be described as 'disused/obsolete materials and goods'. However, the visibility of wastes and its economic value in cities create an important subject for many areas on concern.

WPPs survive from selling waste paper and other waste materials that they collect from public areas. Scheinberg and Anschütz (2005) state that, "Waste pickers recover recyclable materials from mixed waste in street bins, containers, communal collection sites, vacant lots, and final disposal sites. They sell these to dealers and thus indirectly provide local industries with recycled resources" (p. 655). These papers and materials are waste from houses, restaurants, shops, and workplaces. WPPs pick up wastes from city streets and municipal waste receptacles; waste collection is ordinarily a municipal responsibility but municipalities are often ineffective in waste collection and waste recycling in developing countries.

The waste management system in Istanbul is ineffective for two main reasons. First reason is high growth of population due to internal migration, from rural area and other cities to Istanbul, from the early 1980's until now. Second, Istanbul is composed of many small municipalities, which have limited resources, technology to collect wastes effectively, and administrative ambiguity. Agdag (2009) compares old and new municipal waste management system in Denizli, states that, "Rapid urbanization, growth population and changes in lifestyles in developing countries contribute to increasing the per capita municipal waste generation" (p.456). In general, waste management systems are insufficient due to the lack of planning for migration and increased population. Berkun, Aras and Nemlioglu (2005) support this idea saying, "In Turkey, increased population, industrialization, and standards of living have contributed to an increasing amount of solid waste and its consequent ... problems" (p. 847).

From the early 1980's, the rapidly increasing population has had negative effects and created urban problems in Istanbul (Keyder, 1999). No doubt, one of these problems is the waste management system (Ergun, 2005). Unalan (2010), a faculty member of Environmental Engineering in Bosporus University, states that, “... Istanbul suffers from the higher population density and poorly managed ... equity, social justice, basic human needs, employment, poverty, health, urban environment and infrastructure" (p.1). Studies focus on the problems of Istanbul produced by increasing population, which has put enormous burden on Istanbul, and its municipalities for collecting so over municipality to collect wastes (Berkun et al. 2005; Agdag 2009; Keyder 1999; Unalan 2010; Turan, Coruh, Akdemir \& Ergun 2009; Metin, Erozturk \& Neyim 2003).

The report of the Ministry of Environmental in Turkey (Cevre ve Orman Bakanligi - Waste Management Action Plan 2008-2012) expresses that most of solid wastes do not dispose in term of legislations. Further, the report offers some reasons why these wastes have not been disposed properly, including administrative, financial and technical problems. "Presence of a large number of local administrations in the same region composes cooperation and coordination of disposal of waste management complicated" (Waste Management Action Plan 2008-2012, p.7). Disorganization of local administrations causes weak administration, too.

The cost of waste management system is quite high for municipalities. For example, the transportation of wastes from cities to landfill locations and the payment of garbage collectors are two main costs for municipalities (Turan et al., 2009). These three expenditures of settling waste management systems are main reasons effective systems are not constructed. Kanat (2010) argues that, "in recent years, municipal waste management in Istanbul has improved because of strong governance and institutional involvement. However, efforts directed applied research is still required to enable better waste management" (p.1737). Further, Gurdal (2010) argues, solid waste management is one of the major environmental and economic problems in Turkey, as well as in Istanbul.

Ineffective waste management systems in developing countries as well as in Istanbul, creates a job opportunity for "having-nots or want-mores" people to collect then sell these wastes (Agdag 2009; 
Alinsky 1971; Berkun et al. 2005; Gurdal 2010; Metin et al., 2003). Medina (1998) examines the physical characteristic of Third World cities, points that, "their rapid expansion, and the lack of resources to provide them with the necessary infrastructure and urban services, which translate into an insufficient collection of the wastes generated, as well as their improper disposal on the street, vacant lots and in municipal open dumps" (p. 2). Scheinberg and Anschütz (2005) emphasized that in some South countries, such as Philippines, Tanzania, Egypt, Thailand, India, and Cambodia, inequalities of waste management systems lead to an improvement in the livelihood of Waste pickers. Kuria and Muasya (2010) provided an overview of solid waste picker activities in Kenya that paper pickers are important to making cities healthier place, so policy makers should pay attention to their work environment, health and support their informal cooperatives.

Developed countries have the abundance of capital and high labour cost while developing countries have a scarcity of capital and unskilled labour works. Medina (1998) found that because of the lack of recycling programs in developing countries, "recycling activities carried out by waste picker cooperatives ... mostly in Asia and Latin America" (p. 2). In many Asia and Latin American countries, two main reasons, which can be seen in other developing countries, push people into this occupation high population growth and the absence of waste management systems due to insufficient technical equipments and resources. Samson (2009) supports Medina's idea: “...more and more people are likely to turn to waste picking as a survival strategy" (p.1). At the same context, Scheinberg and Anschütz (2005) give example of countries about entrants into waste picking, such as, Argentina, Bulgaria and Roma "gypsies" in Eastern Europe Countries. The characteristics of developing and developed countries differ markedly. Due to these differences, the numbers of WPPs differ as well. As Medina (1998) states, "recycling of municipal solid waste in developing countries relies largely on the informal recovery of materials from waste carried out by waste pickers" (p.28). Thus, I wonder what prompts people to turn to waste picking in Istanbul?

Many others (Bhowmik 2005; Bonner 2008; Chamane 2009; First International and Third Latin American Conference of Waste-Pickers 2008; Samson 2003; Ozgen 2001; Chikarmane and Narayan 2009; Beukering et al. 1996; Medina 1998; Kuria and Muasya 2010) show in their study the contributions of WPPs to society in many ways. They argue that even-though WPPs occupy low economic and social statuses, they make noticeable contributions to society.

\section{Migration and WPPS}

The lack of employment in rural areas has pushed people out of their places of origins to search for jobs in cities (Bhowmik, 2005). Bhowmik (2005) states that, “ ... migrants do not possess the skills or the education to enable them to find better paid, secure employment in the formal sector and they have to settle for work in the informal sector" (p. 2256). The general idea is that most of the WPP are migrants, too. Hayami et al. (2006), argue that one of the most important characteristics of pickers is that they are mostly migrants. Additionally, Scheinberg and Anschütz (2005) state that, "In many countries waste pickers belong to minorities or are internal migrants ..." (p.657). The data of Hayami, Dikshit, and Mishra (2006) show that waste pickers in Delhi, "none of the pickers originated in Delhi and only one collector was born in this city as a son of a migrant, and as much as many as $89 \%$ of pickers and $94 \%$ of the collectors came from rural areas" (p.6). Further studies indicate that informal workers and especially WPPs belong to recent migrants (Kuria and Muasya 2010; Medina 1998; Beukering et al. 1996). As these studies show us, migrants perform waste picking / collecting / recycling in developing countries when they come from rural areas to urban space.

Beukering et al. (1996) interviewed 60 waste pickers, 23 male and 37 female in their study, show that "waste picking is ... resorted to by new immigrants to the city..." (p. 9), and "practically all the respondents were migrants" (p.10). These findings support Huisman's earlier study (1994). Chikarmane and Narayan (2009) examine the profiles and organization of waste pickers in India, Thailand, and the Philippines. They argue that in India almost all waste pickers are under 45 years age and 97\% are migrants (Chikarmane and Narayan, 2009, p.31) Nese Ozgen (2001) shows in her study, Kentte Yeni Yoksulluk ve Cöp Insanlari / New Urban Poverty and Street Waste Pickers, that the majority of waste pickers of Denizli and Samsun provinces of Turkey are migrants. From that information I predict that most of the WPPs in Istanbul are migrants. Some of those migrants were forced to leave their place of origin, others come to Istanbul willingly.

\section{WPPs in Turkey}

Although there are lots of studies about waste paper pickers all over the world, there are few such studies in Turkey. The YOK (The Council of Higher Education in Turkey) thesis center includes several theses about waste paper pickers in Turkey. For example, both Pehlivan (2006) and Soyer (2004) examine waste paper pickers in their environmental engineering theses; these studies, however, 
neither mention the role of the informal sector nor give any information about the people who survive through this job. Rather, they examine waste paper pickers and waste management systems in developed countries from an environmental engineering standpoint (Pehlivan 2006; Soyer 2004). A few other studies have been done about WPPs and their working conditions in Turkey, but they provide only limited literature and information about them and even less about WPP's organizations in Turkey. However, master thesis of Deniz (2010), which examines the informal waste collection sector and waste pickers in Ankara, focuses on the informal waste sector's organization and its inner dynamics. This thesis is especially helpful for my thesis because she conducted interviews with paper pickers who are forced migrants in the Turkozu area of Ankara. Deniz (2010) argues "the literature in Turkey conceptualizes waste pickers as a category of urban poor or utilizes the analysis of waste picking as a tool to understand urban poverty" (p.41). Nese Ozgen (2010) has same argument about WPPs as well. Yardimci and Saltan (2007) examine the perception of 'new urban poverty' in their study, likewise, Ergun (2005) wrote in his master thesis that 'urban poverty' is directly related with the informal sector. He described WPPs as "new informal / par venue sector" (p.85).

Apart from these academic studies, most information about WPPs has been triggered by news, Internet, and broadcast channels. These news stories give positive side and indicate contributions of WPPs to their society. However, most news about WPPs does not draw an optimistic picture.

\section{Methodology}

I used participant observation and participant interview techniques to gather data and investigate WPPs' occupational strategies, inner-dynamics, everyday life, reasons for joining this activity, relationships with other actors in the occupation, why some WPPs remain in this activity instead of leaving, and why they chose an informal occupation. These research questions were investigated through the sociological research methods of depth interview and participant observation.

I thought and discussed about other research methods, especially quantitative research methods, for data gathering. I doubted about finding WPPs as a survey interviewer. One can see them in almost every street of Istanbul; however talking and getting their time is quite complex. Therefore, my first concern was focused on the difficulty of finding participants to fill out a survey. The tactics, maneuvers and inner-dynamics of WPPs cannot be adequately understood through surveys alone.

I audio recorded some of my interviews, while for others I wrote extensive field notes after the interviews. During my participant observations, I took short notes while in the field then wrote extensive notes when I returned home. These interviews, observations and notes provide the data for my study of this informal occupation. By analyzing these recordings and deciphering the responses to my questions, I tried to answer several questions: (1) why people choose this occupational sector instead of getting a more structured, formal, permanent job; (2) what are the living and working conditions of WPPs in Istanbul; (3) what are the relations between WPPs and other actors in the waste collecting and recycling sector; and, (4) what are the experiences and reflections of WPPs' current situations.

WPPs are mostly mobile workers, working individually, and with adaptable working hours. There is a difference between acting and speaking. How people act and speak often portray different things. With a participant observation technique, I shifted my attention away from the way these people talk, but focused instead on their activities in the field; this is one of the strengths of my data. Coming to know firsthand the WPPs' work condition, their stories based on their own words and observing their actions lets me develop an insider's view of their lives and work. From their accounts of events from their daily routine and my observation of those activities, I then categorized those stories and events into a smaller number of themes.

This research talks and listens to WPPs in their work places. Liebow, an anthropologist, pointed out in his research on lower-class American people he studies that; “... they are breadwinner, father, husband, lover and friend" (2003, p.7). Liebow (2003) reminds us that seeing WPPs only as scavengers - that is to focus entirely on their occupational choices and activities - would not give us valid and reliable data on WPPs as persons and actors. WPPs are construction workers, daily laborers, retired men and women, children, students, unskilled workers. They are at the same time fathers, brothers, husbands, wives, sons and friends. I attempted not to see them only as my research objects, but also, over time, as workers and friends.

When I decided to do this research, the question of locating WPPs appeared. I learned by trial and error that making connection with WPPs is not as easy as it seems. I attempted several times to talk with some of them; however, I was rejected most of the time. Therefore, I used social network channels and the snowball technique to locate WPPs.

Neither WPPs nor neighborhoods were selected based on previous knowledge. As in 
Liebow's research, my interaction with my respondents was not due to their pre-selection based on predetermined criteria; rather, "the focus on these particular men at this particular place came about, in large part, through accident" (2003, p. 8). I do not mean all these data have been gathered 'accidently' in the field, but my research took place in central neighborhoods of Istanbul, such as Besiktas, Beyoglu, Avcilar, Ortakoy, and Kadikoy in order to get the information about WPPs occupational dynamics; these neighborhoods were selected because I found informants there.

My research locales includes under the bridge of Besiktas Square, on the streets of Avcilar, in Cennet Mahallesi (a neighborhood in Kucukcekmece in Istanbul), in the streets of Beyoglu, in the Findikli Park in Beyoglu, in Karakoy, and in other areas of Besiktas. The majority of my data were gathered from two-dozen men, two women, and 2 warehouse owners in the field. The major body of the data is recorded in the streets of Istanbul, restaurants, beerhouses, beaches, local parks, buses, warehouses, and under the bridge. I talked, waited and hung out with WPPs almost 16 months, from the spring of 2011 to the summer of 2012.

I went to cheap restaurants with $\mathrm{Baba}^{3}$, went to a tobacco shop with Ali, walked the streets with Baver, and drank tea with Sedat. I worked for a while with Baba ${ }^{4}$ in the field as a WPP. Whenever I walked with him in the streets, I helped him collect wastes in total; I worked one day and night with him. My cousin and I went to a party thrown by Aslan Parcas15's son, who entered the army in February 2012. During the party, I met with Aslan Parcasi's family and participated in traditional dancing with his family members and with others. After that day, whenever he passed my home street, he rings my doorbell and asks about my health. I visited Kirli ${ }^{6}$ in his home, where I got lice and, therefore, itched for a week. Each time I went to Besiktas, I called Biktim ${ }^{7}$ or Baba to have a drink together as a friend. I did not want to interrupt their daily routines and or their work in the field. We sometimes hung around, sat down, ate lunch or dinner, smoked cigarettes, drank tea (although they drank beer or wine most of the time), and collected wastes.

Liebow (2003) describes his first days when he decided to go out and get 'his feet wet'. Liebow says, “....after three of four weeks there was still plenty of suspicion and mistrust" (p.157-158). Similar to his description of his interactions with his informants, when I went to WPPs and asked about their daily routine and inner dynamics over the first two weeks, they thought that I was with the police. So, my plan was talking to them several times.

\section{Description of the Sample}

I interviewed 22 WPPs and two Warehouse Owners (WOs): of my 24 respondents, 22 are male and two are female; both WOs were male. The two female informants do not work independently but with family members. Most WPPs are men with few women working in the field. My informant report that their female co-workers typically work at home separating the wastes their family members collect rather than gathering wastes from the streets.

The mean age of my informants is about 34 years old. The two female informants are 16 and 60 years old. Among the male WPPs, Aslan Parcasi is the oldest, at 64 years old, while Kucuk ${ }^{8}$ is the youngest, at 11 years old. Six of my male respondents are under 18 years old. The twenty-four respondents report educational attainments mostly at the Elementary School level; however, one WPP, Murat ${ }^{9}$, studied at a University, and $\mathrm{K}_{1 \mathrm{sa}^{10}}$ has no formal education. Twelve respondents attained Elementary School education, while five attained either Middle School or High School education. Among those who reached the High School level, Ali completed High School in Germany. Kirli and Sedat left High School without completion. The two female WPPs reached only the elementary education level.

I did not directly ask my informants about their ethnic identification although four voluntarily

\footnotetext{
${ }^{3}$ All the names of Waste Paper Pickers are pseudonyms in order to protect their identity.

${ }^{4}$ After a while, I, like the other WPPs, began to call him Baba [Father] He was the man who took care of other WPPs.

${ }^{5}$ Almost always, he called me 'Aslan Parcasi' [a peace of Lion].

${ }^{6}$ Kirli means 'dirty'. I chose this nickname, because he was the dirtiest WPP I interviewed.

${ }^{7}$ Everybody called him Biktim 'I feel stuffed'.

${ }^{8}$ Kucuk means 'the small one'. I chose this pseudonym because he was the youngest one that I interviewed.

${ }^{9}$ The Last time I saw Murat, he was working in a café in Taksim as a waiter. He was not studying due to financial problems.

${ }^{10}$ Kisa means 'short'. I chose this pseudonym because he was shorter than other WPPs and also other WPPs called him with this name.
} 
identified themselves during our interactions as Gypsy ${ }^{11}$ or Roma. All seasonal migrants conversed with me in Kurdish, indicating a Kurdish ethnic background. In addition, Murat identified himself as Kurdish, too. The remaining study participants seemed to have Turkish backgrounds because the places where they were born and their Turkish accents make me think that they were Turkish.

It was not possible to have long conversations with each informant independently; however, with some of the WPPs, such as Baba, Ali, Sedat, and Biktim, I spent a lot of time. These people were the gate-keepers who allowed me to enter the world of WPPs. In my data analysis, I identified patterns in their conversations that support what I noted during fieldwork. I mostly focused on the migration stories of these WPPs, their reasons for beginning this occupation, the typical day-work of a WPP, and their interaction with each other in the field.

Baba- Baba, now 63 years old, grew up in Izmir although he was born in Eskişehir. He migrated from Izmir to Istanbul at an early age to find a job. He migrated voluntarily. He worked as a truck driver for years and then sold his truck and bought a traditional Turkish tea garden in Istanbul's Kasimpasa neighborhood. He ran this teashop for years. However, some people caused some unwanted events in his shop in 1991. Under the influence of drugs, they arrived at his traditional tea garden and beat Baba's son. They used knives and injured Baba's son, then Baba took his gun and killed three of them. He was sentenced to 28 years imprisonment and, during 14 years of his imprisonment, he was sent to different jails.

Sedat - Sedat, at 48 years old, stays in Balat in a house only for singles. He is from Izmir and migrated to Istanbul 21 years ago. He is not a forced migrant but a voluntary migrant coming to Istanbul to find a better job. Sedat started to work as a WPP when he was thirteen years old in Izmir and has now been doing this work in Istanbul for four years. He is the eldest in his family. He claims that his family thinks that he is working in a kiraathane ${ }^{12}$ as a waiter.

Ali- He is 41 years old, from Samsun. There is an apparent lump on his lip. He has no front teeth, has a 1.75-80 cm long beard, and has white skin. He does not like talking too much. The first day I met with him, he only said hello. Day by day we became better friends. He asked me for cigarettes and wine several times. When he was one year old, his family migrated to Germany. So he attended elementary and high school in Germany.

Mesut-Mesut, 34 years old, is from Tokat ${ }^{13}$. He has been doing this job for 20 years. He works with his father. So, this is a kind of family job. He has three daughters, the eldest is eleven years old, the middle one is ten years old, and the youngest one is three years old. He is 160/165 cm tall; he is a little bit dark, slim and has a kind of cap on his head. He has deep wrinkles on his face. He thinks that dealing with this job for a long time leads to having those wrinkles on his face. He is not stinky and dirty compared to the other people under bridge because he has a family whom he constantly meets. He is not an involuntary migrant; actually his father came here so as to find a job.

\begin{tabular}{cccccc}
\hline Name & Age & Education Level & Place of Interview & Migrant Status \\
Kirli & 56 & Left High School & Tarlabasi & Voluntary \\
Kucuk & 11 & Elementary School & Avcilar & Voluntary \\
Aslan & 39 & Elementary School & Avcilar & Voluntary \\
Mert & 13 & Elementary School & Avcilar & Voluntary \\
Murat & 24 & University & & Taksim & Involuntary \\
Sinan & 34 & Left High School & & Besiktas & Voluntary \\
Selim & 20 (Gypsy) & Elementary School & & Besiktas & Voluntary \\
Erdinc & 14 (Gypsy) & Elementary School & Besiktas & Voluntary \\
Eyup & 12 (Gypsy) & Elementary School & Besitkas & Voluntary \\
Rezzan & 16 (Gypsy) & Elementary School & Besitkas & Voluntary \\
Ali & 41 & High School & Besiktas & Involuntary \\
\hline
\end{tabular}

\footnotetext{
${ }^{11}$ During the interviews, when asked to describe a typical day for a WPP, each of these four informants called themselves Gypsies.

${ }^{12}$ Kiraathane: Traditional tea gardens, where people play card games and so on in Turkey.

${ }^{13}$ A Province in the Black Sea region in Turkey.
} 


\begin{tabular}{ccccc}
\hline Mesut & 34 & Elementary School & Besiktas & Voluntary \\
Kisa & 62 & No Education & Besiktas & Voluntary \\
Biktim & 45 & High School & Besiktas & Voluntary \\
Aslan Parcasi & 64 & High School & Kucukcekmece & Voluntary \\
Ayse & 60 & High School & Kucukcekmece & Voluntary \\
Nesih & 19 (Kurd) & Middle School & Kadikoy & Involuntary \\
Baran & $19($ Kurd $)$ & Middle School & Kadikoy & Involuntary \\
Ersin & $19($ Kurd $)$ & Middle School & Kadikoy & Involuntary \\
Ahmet & $13($ Kurd $)$ & Middle School & Kadikoy & Involuntary \\
Salih (WO) & 50 & Middle School & Karakoy & Voluntary \\
Zeki (WO) & 37 & Elementary School & Karakoy & Voluntary \\
Sedat & 48 & Elementary School & Besiktas & Voluntary \\
Baba & 63 & Elementary School & Besiktas & Voluntary \\
\hline
\end{tabular}

Figure 1: List of Waste Paper Pickers I interviewed

Biktim - Biktim (B1ktım - In Turkish), 45, is from Aksaray in Istanbul. He graduated from Pertevniyal High School ${ }^{14}$ in the Aksaray neighborhood. His height is $170 \mathrm{~cm}$. In my first day under the bridge Ali, Baba and other pickers were talking about how Biktim funny is. He is a very well known person under the bridge. Especially when he is drunk, he sings songs. Furthermore he is really so gentle to the people. He has close relationships with students. Sometimes students come and talk to him, laugh with him. He has been in since he was 20 years old. He has worked as a car washer in the Besiktas Carsi

Nesih - Nesih, 19 years old from Sanliurfa ${ }^{15}$, has seven brothers and sisters. He is the middle brother. His eldest brother is 23 years old and the youngest is three years old. Three of his siblings graduated from middle school but did not continue on to high school. His parents have no formal education and live in a village of Sanliurfa. Nesih graduated from middle school and could not go to high school because of economical insufficiencies his family faced. All young guys of his village have the same kinds of jobs. He has been doing this job for six years. He is proud that his job allows him to send money to his family.

\section{Analysis of Data}

\section{Immigration Story of WPPs}

My data show three main reasons for these immigrants to start this occupation: (1) kinship / relative / friend and compatriot relations, and the social capital present within these network as; (2) the easy entry to this occupation; and, (3) association with the mafia or WPPs being hired on daily basis.

(1) For WPPs, as informal workers, kinship is the first and most often used venue for survival in and adaptation to Istanbul for immigrants. The urging of a relative / friend or compatriot leads them to start this work. In my research, I found this to be the case in many WPP stories. Most WPPs start in this livelihood because they have kin already in this occupation. After immigration, immigrants face an immediate priority in finding a job as soon as possible to maintain life. Hayami et al. (2006) emphasize the importance of relatives and friend relations and their effect on beginning this occupation, saying that, "Typically, when a young man comes from a village to Delhi, it is easy to find an established collector through the connection of relatives and friends. ..." (p. 53). Social scientists emphasize that compatriots and kin are among the fundamental determining factors for immigrants successful adaptation to their place of immigration (Charmes, 2000). For my respondents, the strength of kin ties in Istanbul is the most essential factor determining where the immigrant will settle, what he will do, whom he will meet, and how he will adapt to the new place.

(2) When we consider the requirements for the WPP occupation, that so many immigrants select this work is easy to understand. What follows identifies the requirements for entering the

\footnotetext{
${ }^{14}$ A very well-known high school in Istanbul.

${ }^{15}$ It is a province in South Eastern of Turkey.
} 
occupation and the details of waste picking activities, as described by my respondents. The information provided by my informants corresponds to that identified by other researchers, too (Beukering 1996; Chikarmane \& Narayan 2009; Deniz 2010).

As Sedat explained, setting oneself up in this occupation requires just having 100 lira for buying a hand-truck, being able-bodied, having minimal familiarity with the area where they will work, some knowledge about which wastes are valuable, and so on. Most young adults in Istanbul fit these kinds of requirements. The occupation presents few impediments to entry.

As an occupation, WPP shares the main features with other jobs in the informal sector: "ease of entry; small scale of activity; self-employment, with a high proportion of family workers and apprentices; little capital and equipment; labor intensive technologies; low skills..." (Charmes, 2000, p. 3). All these features are distinguishable in this occupation. Little capital need be invested to start, just enough to buy equipment; modest physical strength, only enough to carry wastes from one place to another; minimal previous work experience, just hands-on instruction which can be gained by doing it with someone knowledgeable for 3 or 5 days (Beukering et al., 1996, p. 11); modest knowledge about marketing, only enough to determine which waste is worthy and where it can be sold; informal work style, primarily working independently and avoid problems with the other WPPs, where to bring wastes, who to sell the wastes to, and for how much to sell them for. All these requirements can be seen in work of WPPs.

From my field observations I noted that a hand-truck for transporting wastes as they are gathered (costing about $100 \mathrm{TL}$ ), along with a pair of gloves (another 10-12 TL) and a metal hook (which can be obtained from rubbish) to pick wastes without touching are the basic tools needed. The metal hook helps WPPs work fast and pick wastes without getting overly dirty. Dirty clothes and shoes are needed to keep them warm and shod.

(3) From WPPs' immigration stories and their accounts of reasons for starting this occupation, I argue that the 'mafia' or hiring WPP on daily basis is a third vital route into the occupation. However, this factor is not mentioned in previous researches in Turkey. During 16 months of field and ethnographic work, I identified a group of people from Adana, a group that can be described as an illegal organization operating in Ortakoy and its neighborhood. Under the bridge of Besiktas, they called this Ortakoy group 'the mafia.' In other words, some people start this occupation, like their peers, because of economic poverty, which they have to deal with. But hiring daily WPPs is a special case. All the WPPs with whom I talked knew about people being hired to work for a man, who has a white car, in the Ortakoy area. Baba, Biktim and Salih were telling me that, "so many people work for both mafia and also for warehouse owners. They lend some money to these WPPs and give them a shelter to stay in, then these WPPs work for them."

\section{Typologies and Interaction of WPPs in the field}

I argue that rather than there being only one type of WPP, they can better be understood as falling into five different kinds of WPPs. Members of Each type differ in work, the way they work, the money they earn, and their relations with local people. Among my informants, some WPPs can be seen to fit into more than one type while others fall only into one. These types are: (1) Old-hand WPPs, (2) Beginner WPPs, (3) Drunk WPPs, (4) Hired WPPs, and (5) Seasonal WPPs. Below, each type is described and compared.

1) Old-Hand WPPs: During my participant observation, I witnessed WPPs go about their daily routine. Every two weeks, usually on Mondays, I would call Baba and met him. On Monday, I called Baba, but there was no answer. Someone answered his phone and said, "The Police packed Baba." "What is 'packed'?" I asked. "It means that, 'police caught him and he is in prison now'," said the man on telephone.

At that moment, I thought about what Baba might have done. I looked for a reason. But all the reasons I thought of was not helping anything but making me anxious. Then, I thought that I should go under the bridge of Besiktas, or the warehouse in Karakoy, or the park in Findikli to find someone we both knew and ask whether that person knew anything about Baba's situation. I walked down the Taksim slope to the Besiktas Bridge; I looked for a familiar face in Karakoy. There were times when I could not contact any WPPs and this was one of these moments. So, before going to the place where Baba rests and has his social relations, I decided to visit to the warehouse and ask about Baba in Karakoy. I tried to find the warehouse. I asked the shop owners nearby, as they all know where it is, and it became easy for me to find it. In the warehouse, there were large sums of solid-waste waiting to be sold. I went inside and introduced myself and asked about Baba.

The warehouse owner answered, "Perhaps Baba may have involved in a fight, and we heard that there were wounded people. The Police arrived there and brought him. What happened, why he fought, whom he wounded, is not known. But he sent me his mobile phone and SIM via cargo. Don't 
worry; he will be released in a few days. What will the state do with people like Baba? They are damage for state."

The most intriguing part of this conversation for me was that Baba had sent only his mobile phone. He did not let his friends know why he was with the police but sent his mobile phone to the warehouse owner. Sending only the mobile phone is a question mark, and sending it to the warehouse owner is another important question mark. Answers to these question marks led me to uncover the functions of mobile phone for the Old-hand type of WPP.

One can argue that everyone has a mobile phone nowadays; there is no special connection between owning a mobile phone and WPPs' inner dynamics. However, I argue that, for Old-hand WPPs, the mobile phone plays a crucial role. I inferred that the most important reason Baba sent his mobile phone to the Warehouse Owner is that, even in prison, he did not want to lose connection with people who give their solid-wastes to him in the Besiktas neighborhood. Old-Hand WPPs' earning strategies differ from those of incipient WPPs. Old-hand WPPs earning does not depend on picking waste from rubbish, bins, and streets as it is generally thought, but instead depends on relationship they have established over time.

I have seen Old-hand WPPs, such as Baba and Salih: they rest and wait for nothing and drink lots of alcohol. They were not in the field like other WPPs. They sometimes collect wastes from the bins area but most of the times hang around.

Once, while we were chatting, Baba said that he knew many people and he showed me his mobile phone contact lists. Baba said proudly, "You will be surprised if you learn what kind of people I know. Many rich men, accountants, bankers, shop owners, apartment owners, market owners, stationers, restaurant owners, etc." He had approximately 500 contact names in his mobile phone. Baba continues, "We got most of the wastes from offices and companies. No matter the hour, they call us. We go and pick them to sell."

These two informants have been WPPs for more than ten years, but the way they earn money and the way they work are different from other types of WPPs. They have developed a useful network and which plays a vital role in their earnings. This relationship is invisible to naked eye, but becomes visible through interviews, participant observation and ethnographic work. Old-hand WPPs have to get on well with people - developing warm and intimate relations has great importance for Old-hand WPPs.

The significance of the mobile phone in this occupation is related to the job itself. Typically, most WPPs do not spend all their time in the same place, they always move from one place to another. They do not stay on in one place for more than five minutes if they are not resting or chatting with each other. In a way, since it is a mobile job, their obligation to move requires them to use a mobile phone. However, it is hard to say same thing for Old-hand WPPs.

Baba has set up a social network for himself in Besiktas, Karakoy, and Findikli. Building this network did not happen in a short time; it took years of working and mutually knowing each other. For instance, Baba and Simitci helped each other and in the same way, his relation with shop owners is really intimate. This mutual benefit relation is important for Baba, for other WPPs and for the tradesmen in the neighborhood. 'Here is my district', I argue that this sentence just can be heard only from Old-hand WPPs, because it depends on their relation that they own during years time.

Gaining money depends on phone calls coming from local people, companies, market owners, and restaurants. By these calls people ask them to pick wastes at a specific time. These wastes may include paper, copper, old refrigerators, household objects, plastics, etc. An unanswered call not only means lose of money but also may ruin his relations.

2) Beginner WPPs: Collecting wastes directly from the streets is mostly done by Beginner WPPs. Except for Old-hand WPPs; all types of WPPs collect wastes from streets. However, Beginner WPPs are mostly young people, often very young people. For these people survival and earnings depend on experience and relationships with others, especially with more experienced WPPs.

The following stories of Beginner WPPs highlight the reason to categorize them with this name. Beginner WPPs are mostly kids, such as Kucuk, Mert, Selim, Rezzan, and Erdinc. Further, four of these respondents are Gypsies, and are all under 18 years old, except for Selim, who is 20.

As Omer and Mert said, "We wake up at 7 am to go to school and come back home at $12 \mathrm{pm}$. Then we have to help to our family to divide the wastes. We come here at $7 \mathrm{pm}$ until 2 am in the morning". Obviously, these children are aware of their family situation and they talk with 'have to' sentences.

I wanted to talk with a woman WPP, but could not get in touch with one easily. So, I asked for help from one of my female friends. I had seen some woman WPPs around Besiktas Carsi. I went there with my friend in an early morning; there were some young and female WPPs in front of Starbucks. I thought I could make an interview with both the kids and female WPPs. I introduced myself and asked 
kindly whether they would talk with me. Since it was early morning, I invited one of them, whose name is Selim to have a tea with us. He joined us and had a tea. I asked whether he had had breakfast or not. He shook his head, saying no. I went to a patisserie and bought some pastries. Once we settled down and were ready for a conversation, Erdinc and Eyup came forward and asked to join us. I think, they had been watching us from the corner. Once we had tea and pastries, they wanted to join us. Suddenly, we become five at a table. However, my mind was busy with how to invite their female friend who was sitting nearby on the sidewalk and watching us. After a while, I asked Selim, "Why don't you invite your friend," pointing to the female WPP. He called her and she, Rezzan, came. However, she was quiet and talked little.

During our conversation, Selim talked the most. Other WPPs was busy eating and drinking. We talked about why they started this job. Selim said, "We are Roma (Gypsy). My family does this, so I do." The other WPPs, including Rezzan, nodded their heads. Selim explained him the eldest in that group. He was 20 years old, while Erdinc was 14, Eyup 12, and Rezzan 16 years old.

Selim continued, "We are not staying here all the time. For instance we were in Bakirkoy ${ }^{16}$ last year, but this year we come here. Do you remember, there was an explosion in Bakirkoy last year, the explosion of propane cylinder in a home, at that time I was collecting wastes just on that street. I was scared a lot. I have not feared that much in my life." This explosion was something special for him. He continued, "Police forces were looking for me, because they had asked to some other WPPs and they went to the warehouse and showed my picture to the owner. They had my picture. They got my picture from street cameras of some other shops. Anyway, I was afraid a lot and went to the police center. They captured me immediately and asked me hundreds questions. After they figure out that this was not a bomb but explosion of a propane cylinder, they let me go." I did not want to interrupt his speech about that explosion, because he looked eager to talk about this issue. However, from this conversation I see that this group of WPPs works in different neighborhoods of Istanbul, they were mostly young people, and they are kin to each other.

I asked him about their relationship with local artisans; he said, "Abi ${ }^{17}$, I will go to the army in two months and I have some debt that I should pay before I go, that's why I came here. And also these are my kin. My brother and I work together, he went to Yildiz Yokusu. He will come back soon." He did not give an answer about their relationship with local artisans, so I asked in another way that, "Do you know any local shopkeeper here?" He answered, "No, I don't know anyone here. We came here a week ago. In the summer time, we stay outside. For instance, we came here from Esenyurt for one week. We collect wastes for a week then we carry them from here to there."

From this point of view, I asked him to describe how they carry these goods from Besiktas to Esenyurt, which are around $70 \mathrm{~km}$ apart. He answered happily, "Abi, our warehouse owner has a big truck, and he comes and takes us and all the wastes from here to there." Even though Selim started this occupation four years ago, he can still be called a beginner WPP. When we compare Old Hand and Beginner WPPs, the first area where they differ is their relation with local people, police forces, and local warehouse owners. First, Beginner WPPs have a little connection with local people and shopkeepers, as Selim explained. Second, they do not stay in one place long enough to get to know other WPPs and local people. For instance, Baba comfortably could say, "Here is my district," but these Beginner WPPs do not have the same kind of connection to local people. Third the way they make money also differentiates Old-Hand and Beginner WPPs, instead of hanging around waiting to be called to pick up some trash, mostly work in the field. Fourth, even though Beginner WPPs work in several different neighborhoods, they nevertheless sell their goods to the same warehouse owner. Beginner WPPs depend more than do Old Hands on experience and relationships with others for survival and earning money.

3) Drunk WPPs: Baba, Salih, Biktim, and some other WPPs have a habit: sitting by the Bosporus, drinking alcoholic beverages, and discussing the politics of Turkey. Findikli Park is their preferred gathering place, where they get together, rest, sleep in summers, and get news from each other.

Drunk WPPs drink alcohol whenever they find free time. I have hung around with those Drunk WPPs a lot. While hanging around, I was not aware of the importance of their being almost always drunk. After spending more time with them, I remembered thinking, "These are drunks. That is all! There is nothing for me to understand." With this attitude, I began to hand out with them less than I had before. However, again, as usual, one of Baba's conversations made me think more deeply about WPPs.

I was trying to understand the warehouse owners' role in and impact on this occupation. Baba

\footnotetext{
${ }^{16}$ It is a municipality of Istanbul.

${ }^{17}$ To show his respect, he used $A b i$, a Turkish word, meaning 'Big Brother'.
} 
explained to me and said, "I don't work with all warehouse owners. Actually it is hard to work with them, too. For instance, how can I work with the warehouse in Tarlabasi? Tarlabasi is in nowhere... And also, for instance, even though it is close I don't give my wastes to the warehouse in Bogazkesen Yokusu $^{18}$ either. It has different reasons. I give my wastes to the Karakoy warehouse. Because, there, the price of waste have changes little for me. Maybe it is not big differentiation between prices, however once you count it kilo by kilo, you figure out that the weight is high so this small amount of money becomes a big number." Baba continues describing Bogazkesen Yokusu warehouse owner's attitude, pointing out that, "Bruv, this man is Hac1/Hoca, doesn't receive goods from me. I went there a couple of times, but I smelled of beer. He warned me not to come over there again."

Even though the price of wastes in the Bogazkesen Yokusu warehouse is better than those at the Karakoy warehouse, these Drunk WPPs do not sell wastes to the Bogazkesen Yokusu warehouse. This knowledge helped me understand that there are different kinds of WPPs and one of them is Drunk WPPs. The money they make, the way they live in the street, and people's attitude for them is different from other WPPs. Baba's statement shows as well that the WPPs recognize these differences in the inner-dynamics of WPPs world, it makes different. The money they earn and the way they work is different than other kinds of WPPs typologies.

From Baba's explanation, we see that Drunk WPPs earn less money than do other kinds of WPPs. I do not argue that it is one of the main characteristics of Drunk WPPs circumstance; however I see that they earn less money.

The way Drunk WPPs spend their money differs from that of other types of WPPs. For example, Sinan - a 34 year old, bald, short, and stinky WPP under the bridge, was so drunk that could not walk straight one night, and Baba pointed to him and said, "Look at this stupid head, Hoca. I don't know how he drinks that alcohol. He has no balance once he drinks. Ok, we drink this shit too, but the way he drinks is just too much." Baba was criticizing Sinan for drinking excessive alcohol. However, while he was telling this he had a beer on his hand.

Baba continues, "Hoca, I don't tell anyone not to drink alcohol, this is not my business. But what I say is, if you drink this shit you should eat too. Otherwise it will let you down so fast. Look at me, I look younger than him, because I eat." Baba's main concern focused on the Drunk WPPs' daily situation. He wanted other Drunk WPPs to quit their drinking. I think that since he was both a Drunk and an Old-Hand WPPs, he was trying not to have any problem with local people and the police. Therefore, he was trying to get the over-indulgers to quit. Drinking alcohol was something accepted by Baba; however, if one loses self-control after drinking alcohol, Baba gets angry with the person.

In my fieldwork experience, I noted that after selling the goods, the first thing Biktim and Baba did was to buy beer and go to Findikli Park. This was kind a habit for Drunk WPPs in that neighborhood. Baba, Biktim, Salih, Sinan, and Ali have either no relation or a little with their family, in previous I had give their stories. Rather, these Drunk WPPs spend the money they earn for buying alcohol; the main concern for them is not earning money for survival but for drinking alcohol; they have either no or little contact with their family members; their relations with warehouse owners in the field is different than other kinds of WPPs.

4) Hired WPPs: At this stage, I would like to clarify the situations of Hired WPPs and their relationships to warehouse owners.

On my second visit, the warehouse owner told me that he had had to close the second floor due to a disagreement about the rental price. While we were speaking, four people were building a double-decker structure near the place on the first floor where they classify wastes. I asked the Warehouse Owner why they were doing that double-decker and he replied me, "What could it be? I build a double-decker for WPPs to sleep on. They get cold while they sleep on ground, and it is cold already. I can't make an effort to take care of illnesses."

From an external perspective, it appears that the warehouse owner takes care of the WPPs and protects them against the cold. However, this would be very naive interpretation since the warehouse owner's real character manifests itself in this situation. "Warehouse owners use some WPPs to work for them as wage workers," said Biktim, Baba, Kirli and Salih each told me. In other words, WPPs, who work for a wage (around 20-25 TL per day) including lodging and meals, collect solid-waste to give to their warehouses. These are both seasonal (as we could define them), and hired WPPs.

From this situation rises the idea that some WPPs are not their own bosses. Consequently, in the Karakoy warehouse owner's situation, he wants to guarantee these WPPs working for him so he provides them lodging and meals. The double-decker meets two needs: by providing WPPs a place to sleep it also guarantees the WO a steady workforce. Moreover, each day a WPP gets sick as a result of sleeping on the ground and does not work causes the warehouse owner to lose money. The interview

\footnotetext{
${ }^{18}$ It is a district in Beyoglu neighborhood.
} 
held in Ankara with WPPs reported helps clarify the situation (Ataogul 2010), "There are some WPP who stays at warehouses, too. In most cases there are shakedowns laid on the ground at some warehouses." Similarly a Turkish journalist living in Canada had this conversation with a WPP in Kadikoy.

"How much do you earn from this occupation?" he answered, "I make 30-40, sometimes 20 liras." She continued with another question, "Is it daily?" The answer was, "Yes. Sometimes 10-15 TL though. When the municipality confiscates our hand-truck, the warehouse owner cuts 90 TL from us." From this point she asked another question, "All right, how does this happen? Does the warehouse owner give you the hand-truck?" He answered, "Yes, you take the hand-truck and set out. We collect from Suadiye, Kadikoy, Caddebostan, and Bostanci." Her final question was, "Then you give whatever you've collected to warehouse owner and he gives you money, is that right? I mean do you get your money daily?" The answer is, "Yes, sometimes weekly." (Ataoğul 2010)

The warehouse owner in Karakoy is not alone in using this tactic; others use this method, too. Warehouse owners are able to steer workers in their sector by developing new tactics. The social network that they have built as a consequence of their different connections provides them this opportunity.

Hayami et al. (2006) explain that new immigrants mostly work as apprentices and stay at junk stores in the beginning. This apprentice-mastery relationship and staying at junk store situation act as a "contract" between the waste gatherers and the middlemen. Hayami et al. refer to this situation as follows: "According to this contract, the dealer lends a rickshaw cart free of charge and gives cash ... to the collector. The dealer also advances emergency- relief credits in the event of the collector's sickness or accident. For these benefits the collector is obliged to sell all his collections to the dealer at about 5 percent lower prices than those prevailing in the market" (p.53). WPPs in Delhi and their relationship with their warehouse owners differ from those in Istanbul in the context of community mechanisms. The most significant difference is that a WPP in Delhi is under the care of his/her warehouse owner in case of health problems or accidental situations. Further, WPPs in Istanbul need to supply the equipment that they need themselves. In Turkey, the WPP does have a contract with the warehouse owner.

I do not claim that all warehouses operate WPPs in the same way as hired workers or cooperate with capital owners in order to exploit labor. In her master's thesis, Deniz (2010) discusses warehouses and suggests that there are different kinds of warehouses. All warehouses do not operate their WPPs in the same way. For example, some warehouses deal with their WPPs seasonally.

5) Seasonal WPPs: Nesih and his siblings illustrate the seasonal WPP situation. As Nesih explains, he and his siblings work as seasonal workers in different parts of the country at different times. With their large family, they prefer staying in a house together rather than staying at a warehouse. However, those who begin this occupation individually, instead of in a group, often prefer immediately beginning work under the control of a warehouse. Mendillioglu addresses this subject in the interview that he gave to BirGun Newspaper, “...there are seasonal workers, people who come from abroad to do this job as well. There are people who come from Georgia and Turkic Republics and who work seasonally here. There are ones who are coming from East and Southeast. For instance, 300-400 people in Ankara came from Urfa-Siverek and Diyarbakir to work seasonally... They do seasonal farm labor in Ankara-Polatli and when they finish there, they come here and collect paper. Eventually, they go back to their hometown" (Mercan 2010, p.1).

\section{Conclusion}

This study explored the intersection of issues of migration, ethnicity, stratification, and the informal economy, particularly focused on Waste Paper Pickers (WPPs) as an informal occupational group in Istanbul. I conducted a yearlong fieldwork project among WPPs in Istanbul, collecting ethnographic, observational, participant observational and interview data to develop a description of the everyday life of WPPs and how they organize their daily work routines. This study identified most WPPs as immigrants enmeshed in family, friend and compatriot relationships and examined WPP occupational inner-dynamics. This study examined on internal, legal migrants, some voluntary and some involuntary, and on these migrants' experiences in the informal economy. This is an exploratory qualitative work; it does not test hypotheses nor generalize beyond my sample of informants. However, triangulation among several research techniques (interview, observation, and field work with participant) permits me to identify and categorize important characteristics of this sample of Istanbul WPPs.

This research shows that waste management system is not sufficient to meet the needs in developing countries so informal systems of waste management grow. A review of the literature on waste pickers in other countries shows that most third world countries face rapid urbanization, which is 
so similar to Istanbul, with fast population growth and migration, and the strategies for dealing with the effects of these problems differ in different countries. The cost of waste management system is quite high for municipalities. Administrative, financial and technical costs lead to ineffective municipal systems but simultaneously create niches for informal solutions.

Waste Paper Picking is also an occupation chosen by some who find the remuneration of a formal job insufficient compared to informal jobs. In general, WPPs find places within the system in which live to a suitable place for to survive. However, as De Certeau explains, "They remained other within the system." (1988, p. 32) In my research, WPPs portrayed themselves as largely external to society, but one to which 'they assimilated and which assimilated them externally'. They are migrants, unskilled, children, alcoholics, and women. At the same time, they are fathers, brothers, friends, sisters or sons. It is important to see them not only as Waste Paper Pickers but also to see their relationships with others in their own environment. For passersby who see only the surface of WPPs, they are only dirty, stinky, unskilled, illiterate, criminals or petty thieves. WPPs know that people see them not as people but as something else. "Without leaving the place where he has no choice but live ... he establishes within it a degree of plurality and creativity," De Certaue notes in his book (1988, p. 30) and, I acknowledge that this is exactly what WPPs do under the bridge of Besiktas, in Karakoy, in Findikli.

To understand WPPs in Istanbul, one must show the links between the occupation and immigration. All my informants were migrants to Istanbul. They left their homes and came to the city for different reasons, including economical insufficiencies in their places of origin, forced displacement for socio-political reasons, pull factors of Istanbul and push factors of emigrant place. But each of my informants shares how the immigration experience has a vital impact for understanding their occupational dynamics. WPP immigration stories help us to understand both how migrants connect to each other - mostly through family, citizenship, ethnic background, social links the sources of their social capital in Istanbul - and thus their reasons for entering the WPP world.

WPP migrations stories reveal patterns that drove people to enter this occupation after migration. My data show three main factors that account for these immigrants entering this occupation: (1) kinship / relative / friend and compatriot relations, (the social capital that those people have); (2) the easy entry to this occupation; and, (3) the mafia or hiring WPP on daily basis.

Rather than only one type of WPP, they can better be understood as falling into five different types. WPPs in each type differ in their work, the way they work, the money they earn, and their relations with local people. Among my informants, some WPPs can be seen to fit into more than one type while others fall only into one. These types are: (1) Old-hand WPPs, (2) Beginner WPPs, (3) Drunk WPPs, (4) Hired WPPs, and (5) Seasonal WPPs.

\section{References}

Agdag, O. N. (2009). Comparison of old and new municipal solid waste management systems in Denizli, Turkey. Waste Management, 29(1), 456-464.

Ataogul, A. S. (2010). Avrupa Kultur Baskenti Istanbul 'dan Goruntuler. Bizim Anadolu Internet Newspage. Retrieved on June 18, 2012 from http://www.bizimanadolu.com/koseyazarlari/ayinkonugu24.htm.

Alinsky, S. D. (1989). Rules for Radicals: A Pragmatic Primer for Realistic Radicals. New York, NY: Random House.

Berkun, M., Egemen A. \& Semih N. (2005). Disposal of solid waste in Istanbul and along the Black Sea coast of Turkey. Waste Management, 25(8), 847-855.

Beukering, P., Schoon E. \& Ajit M. (1996). The Informal Sector and Waste Paper Recovery in Bombay. CREED Working Paper Series 5 (54 pages), Retrieved on March 1, 2011, from www.premonline.org/archive/17/doc/creed05e.pdf.

Bhowmik, S. K. (2005). Street Vendors in Asia: A Review. Economic and Political Weekly, 22562264.

Bonner, C. (2008). Waste pickers without frontiers. South African Labour Bulletin, 32(4), 7-9.

Chikarmane, P. \& Laxmi N. (2009). Rising from the Waste - Organising Wastepickers in India, Thailand and the Philippines. Bangkok, Thailand: Committee for Asian Women Research Paper Press.

Chamane, M. (2009). South Africa's Waste Pickers Creating Jobs and Fighting Poverty. South African Labour Bulletin 33(2), 22-24.

Charmes, J. (2000). African Women in Food Processing: A Major, But Still Underestimated Sector of Their Contribution to the National Economy. Paper prepared for the International Development Research Centre (IDRC), Retrieved 5 May, 2012 
(http://wiego.org/publications/african-women-food-processing-major-still-underestimatedsector-their-contribution-nati).

Çevre ve Orman Bakanlığı. (2008). Waste Management Action Plan 2008-2012 (Atık Yonetimi Eylem Plani 2008-2012). Ankara: Çevre ve Orman Bakanlığı Yayiinlari.

Deniz, G. C. (2010). The informal waste collection sector and the waste pickers; a case study in Ankara. Master of Arts in History Degree in Boğaziçi University, Istanbul. Retrieved on December 25, 2010, from http://tez2.yok.gov.tr/.

De Certeau, M. (1988). The Practice of Everyday Life. London: University of California Press.

Ergun, C. (2005). Yoksulluk ve Enformek Sektor: Cöp Toplayicilari Ornegi (Isparta-Izmir Karsilastirmasi). Master of Arts in Sociology Department in Süleyman Demirel University, Isparta. Retrieved on December 25, 2010, from http://tez2.yok.gov.tr/.

Hayami, Y., A. K. Dikshit \& S. N. Mishra. (2006). Waste Pickers and Collectors in Delhi: Poverty and Environment in an Urban Informal Sector. Foundation for Advanced Studies on International Development 2003-004. Retrieved on March 2, 2012 http://www.povertyenvironment.net/node/748.

Huisman, M. (1994). The Position of Waste Pickers in Solid Waste Management. In: I. Baud and H. Schenk (eds.) Solid Waste Management: Modes, Assessments, Appraisals and Linkages in Banglore (pp. 46-104). New Delhi: Manohar.

First International and Third Latin American Conference of Waste-Pickers. (2008). Bogota, Colombia, 1-4 March 2008. Retrieved on March 24, 2012, from http://globalrec.org/global-meeting/latinamerican-colombia-2008/

Kanat, E. (2010). Municipal solid-waste management in Istanbul. Waste Management, 30 (8-9): 1737 1745.

Keyder, C. (1999). Istanbul Between the Global and Local. Lanham, Maryland: Littlefield Publishers:

Kuria, D. \& Rina M. (2010). Mapping of Waste Pickers and Organizations Supporting Waste Pickers in Kenya. Cambridge, MA: Women in Informal Employment: Globalizing and Organizing (WIEGO).

Liebow, E. (2003). Tally's Corner: A Study of Negro Streetcorner Man. New ed. Lanham, MD: Rowman \& Littlefiled Publishers.

Medina, M. (1997). Informal Recycling and Collection of Solid Wastes in Developing Countries: Issues and Opportunities. Tokyo: United Nations University / Institute of Advanced Studies Press. (1998). Scavenger Cooperatives in Developing Countries. BioCycle, 70-72.

Mercan, M. (2010). Onlar Kağıt İşçileri... Onlar yaşamak için çöple boğuşuyorlar. BirGün Newspaper, January $05 . \quad$ Retrieved on June 16, 2012, from http://www.birgun.net/worker index.php?news code $=1262695410 \&$ year $=2010$ \& month $=01 \&$ $\underline{\text { day }=05 .}$

Metin, E., Erozturk, A., \& Neyim, C. (2003). Solid waste management practices and review of recovery and recycling operations in Turkey. Waste Management, 23(1),425-432.

Ozgen, H. N. (2001). New Urban Poverty and "The Scavengers" (Street Waste Pickers). Toplum ve Bilim 2001(89), 88-101.

Pehlivan, Y. (2006). The Evaluation of Waste Papers within the Wastes Recycling and the Analysis of its Economic. Institude of Science and Technology in Gazi University, Ankara. Retrieved on March 20, 2011, from http://tez2.yok.gov.tr/.

Samson, M. (2003). Dumping on Women: Gender and Privatization of Waste Management. South African Municipal Workers' Union (SAMWU).

Samson, M. (2009). Wasted citizenship? Reclaimers and the Privatised Expansion of the Public Sphere. Africa Development 34, 1-25.

Scheinberg, A. \& Anschütz, J. (2005, January). Slim Picking's: Scavengers and Waste Pickers in the Modernization of Urban Waste Management System in the South. The Conference Proceeding of Waste: The Social Context, 653-670.

Soyer, N. (2004). Environmental standards for paper and pulp industry and waste paper recovery in Turkey in accordance with European Union. Masters of Environmental Studies in Yildiz Technical University, Istanbul. Retrieved on March 20, 2011, from http://tez2.yok.gov.tr/.

Turan, N., S. Coruh, A. Akdemir \& Ergun, O.N. (2009). Municipal solid waste management Strategies in Turkey. Waste Management, 29(1), 465-469.

Unalan, D. (2010, November). Sustainability of New Urbanism: A Case from Istanbul. Third International Conference on Next Generation Infrastructure Systems for Eco-Cities, Shenzhen, China.

Yardimci, S. \& Saltan, A. (2007). Geri Donusumun Gorunmeyen Yuzu: Sokak Toplayicilarinin İs ve Yasam Kosulları Uzerine. Toplum ve Bilim 108, 206-239. 